\title{
BENTHIC-PELAGIC COUPLING AND POSTDEPOSITIONAL PROCESSES AS REVEALED BY THE DISTRIBUTION OF OPAL IN SEDIMENTS: THE CASE OF THE RÍA DE VIGO (NW IBERIAN PENINSULA)
}

\author{
Patricia Bernárdez 1,2,", Guillermo Francés ${ }^{1}$, Ricardo Prego ${ }^{2}$ \\ 1 Departamento de Geociencias Marinas y Ordenación del Territorio, Facultad de Ciencias del Mar, \\ Campus Lagoas Marcosende s/n, Universidad de Vigo, 36310 Vigo, Spain. \\ 2 Departamento de Oceanografía, Grupo de Biogeoquímica Marina, Instituto de Investigaciones \\ Marinas (CSIC). C/ Eduardo Cabello 6, 36208 Vigo, Spain.
}

Manuscript received July 7, 2005

*Corresponding author. E-mail address: pbernardez@uvigo.es

Tel: +0034986812633

Fax: +00 34986812556 


\section{Abstract}

Opal concentrations in dry bulk sediment were measured in forty three sampling stations in the Ría de Vigo at $0-1,1-2,4-5,10-11$ and $14-15 \mathrm{~cm}$ sediment depths. The amount of opal was correlated with the biogenic silicon flux to the sediment obtained by means of a box model. The biosiliceous flux to the sediment (annual mean) is in good agreement with the content of opal found in the uppermost oxic layer, revealing that pelagic primary production is the main factor controlling the biogenic silica content in surface sediments. This correlation is illustrated by the equation: Opal $(w t . \%)=0.103 \mathrm{BSiF}+0.414,\left(\mathrm{R}^{2} 0.95\right)$ where BSiF is the biogenic silicon flux to the sediment in $\mathrm{g} \mathrm{Si} \mathrm{m}^{-2}$ year-1. In the innermost part of the ria, i.e. San Simón Inlet, the content of opal is higher than predicted by the equation, since other biogenic silica sources to the sediment may be involved, as benthic diatoms proliferation or freshwater diatoms input. Elevated percentages recorded in the inner ria in the subsuperficial sediment are respond to the establishment of suboxic-anoxic conditions that enhance the preservation of opal. The input of faecal pellets to the surface sediment derived from mussel rafts also controls the opal distribution and concentration in the ría.

Keywords: opal, surface and subsurface sediments, biosiliceous flux, ría, Galicia 


\section{INTRODUCTION: BACKGROUND AND OBJECTIVES}

Silicon is an essential parameter in the ocean because is a major nutrient required by phytoplanktonic primary producers. The biogeochemical cycle of silicon is driven by the biomineralization of opal by diatoms and other organisms in ocean surface waters followed by dissolution of the biogenic silica after the organisms die. Remains of this organisms sink to the sediment providing to opal a high potential as a proxy of paleoproductivity. However, a small fraction of the biogenic silica is buried and preserved in marine sediment. In coastal areas biogenic silica content is normally low as a result of the high terrigeous input, so its utility has been questioned (Nelson et al., 1995). Recent progress performed in the study of the silicon marine cycle suggest that the use of opal as a paleoproductivity proxy can be looked at in a more optimistic view. There is a crucial need for a better calibration of this marker in order to improve our capacity to interpret the opal burial in the sediment in terms of paleoproductivity and paleoceanography. The main factors that involve the linking between surface production and the biogenic silica burial are the spatial and temporal variations of preservation efficiency, lateral advection, sediment redistribution and the uncoupling between Si and C biogeochemical cycles (Ragueneau et al., 2000). These factors create discrepancies between export and sedimentary siliceous fluxes at a global scale (Nelson et al., 1995).

Controls on biogenic silica dissolution and preservation in marine environments are complex. The transfer processes of biogenic silica from surface waters to the sediment are controlled by the competition between physical export and biogeochemical recycling. Several factors such as availability of dissolved silicate for growth, temperature (DeMaster, 1981) and trace element chemistry of the seawater (van Bennekom et al., 1991), silica recycling in the water column (Nelson 
et al., 1995), seasonality (pulses of primary production), supply rate (Pokras, 1986), lateral transport and resuspension events, selective grazing or the formation of aggregates (Pasow et al., 2003) and faecal pellets play also an important role. Dissolution of biogenic opal starts within the water column, and continues in the sea floor, where the processes related to preservation of the settling material to the sediment are numerous and poorly understood, namely: post-depositional dissolution and early diagenesis in the sediment matrix (Ragueneau et al., 2001), sedimentation rate (Pokras, 1986), benthic activity, and bioturbation that enhances the mixing of pore fluids and increases the removal rate of dissolved silica to the overlying water column, abundance of the lithogenic particles and the corresponding influence of aluminium concentrations in opal solubility (Van Cappellen and Qiu, 1997), and the kinetic and thermodynamic conditions affecting the opal solubility.

Despite these inconveniences, the information derived from content of biogenic silica in the sediment combined with other productivity markers in a multi-proxy approach is useful. Research is commonly focussed on surface sediments to ascertain spatial changes in pelagic primary production. Opal-rich sediments are associated with high primary productivity in coastal areas however, data on biogenic silica content (BSi) in estuarine and coastal sediments are relatively scarce.

One of these areas is the Galician coast and adjacent shelf. Previous studies on opal distribution in the rías (Barciela et al., 2000; Dale and Prego, 2002; Cobelo-García and Prego, 2004) and continental shelf (Prego and Bao, 1997) were limited to the surface sediment $(<2 \mathrm{~cm}$ depth, uppermost oxic layer), and have the limitation of a low resolution mapping. The Ría de Vigo has been targeted as the subject of research aimed at understanding its hydrography, nutrient cycles, primary production and plankton communities. Although, the Ría de Vigo has been researched thoroughly, little information is available about the record of productivity in the sediments since a very limited number of studies have been carried out to date. Prego et al. (1995) evaluated the silicon cycle 
focusing in the water column processes, including phytoplankton taphocenosis in the surface sediments in relation to upwelling non-upwelling events. Also, Bernárdez et al. (2005) have reported values of biogenic silica in the uppermost oxic layer, which are strongly correlated to spatial variations in primary productivity.

Thus, on the basis of a high resolution mapping and a description of the distribution of the amount of opal in a Galician Ría, the aims of this study are (1) to map the opal content and its local changes in the surface and subsurface sediments in the Ría de Vigo and (2) to correlate the opal record in the surface sediments with the biogenic silicon fluxes from the surface waters to the seabed.

\section{STUDY SITE}

The Ría de Vigo is the southernmost one of a set of four incised valleys (Rías Baixas, NW Iberian Peninsula), where long term climatic variability has changed the extension of the estuarine zone through time (Evans and Prego, 2003). The physiography of the ria shows a funnel-like shape in plan view, gradually widening seawards, and is partially enclosed by the Cíes Islands resulting in relatively calm conditions in the ría (Fig. 1). The most important freshwater input to the Ría de Vigo comes from the Verdugo-Oitabén river that flows into San Simón Bay, at the landward head of the ría. The annual freshwater flux is $26 \mathrm{~m}^{3} \mathrm{~s}^{-1}$, but the freshwater contribution varies monthly from 30 to $56 \mathrm{~m}^{3} \mathrm{~s}^{-1}$ during the rainy season (November-March) until 2 to $12 \mathrm{~m}^{3} \mathrm{~s}^{-1}$ in the wet season (JuneOctober) (Pérez-Arlucea et al., 2000 and references therein). 
The Rías Baixas are influenced by a seasonal quasi-permanent upwelling, usually occurring from spring to September or October (Fraga, 1981). This process is driving by the northerly trade winds where the resulting baroclinic pressure gradients in the rías are compensated by intrusions of the cold, nutrient-rich, sub-surface oceanic East North Atlantic Central Water, ENACW. Therefore, residual circulation is strongly influenced by coastal upwelling dynamics (Fraga 1981). The ría is characterised by a two-layered residual circulation pattern, with freshwater ouflow at the surface balanced by the inflow of saltier water in the lower layer. In winter, river discharge favours the positive estuarine circulation, but during summer, stratification is maintained by the vertical distribution of the temperature in spite of the river flow (Prego and Fraga, 1992). The density-driven flow is influenced by wind regime rather than by the other weather conditions such as continental runoff and heat exchange with the atmosphere (Álvarez-Salgado et al., 1993). Southerly winds promote coastal downwelling, and thus the surface inflow of surface oceanic water with relatively high thermohaline variability and low nutrient content.

The annual cycle of primary production in this region is controlled by the inflow pulses of ENACW during upwelling, with peaks of biomass during late spring and summer. Due to this upwelling situation, the Rías Baixas are among the most productive oceanic regions in the world being subjected to important human activities of economic interest such as mussel production. Consequently, the ría sediments have typically high contents of organic matter and opal (Prego et al., 1995; Bao et al., 1997; Barciela et al., 2000; Dale and Prego, 2002; Bernárdez et al., 2005). In the Ría de Vigo, mean annual values of net primary production are about $350 \mathrm{mg} \mathrm{C} \mathrm{m}^{-2} \mathrm{~d}^{-1}$ (Prego, 1993) but during the upwelling season in 1997 Gago et al. (2003) reported a net ecosystem production of $790 \mathrm{mg} \mathrm{C} \mathrm{m}^{-2} \mathrm{~d}^{-1}$. High values of around 700 and $1200 \mathrm{mg} \mathrm{C} \mathrm{m}^{-2} \mathrm{~d}^{-1}$ were also found in the Box 2 and 3 (Fig. 1), and especially from spring to autumn with ría peaks ranging from 2100 to $2800 \mathrm{mg} \mathrm{C} \mathrm{m}^{-2} \mathrm{~d}$ - 
1 (Fraga, 1976; Tilstone et al., 1999; Moncoiffé et al., 2000) as a result of the fertilization of surface waters when upwelling occurs. Several authors have also reported important spatial variations in primary productivity within the ría, suggesting a general decreasing trend from head to mouth (Prego 1993 and references therein).

The grain-size distribution of the seabed consists of mixed siliciclastic and bioclastic gravels in both the outer area and the boundaries of the ría, and a major axial deposit of cohesive sediments in the middle ría, whereas the inner areas are dominated by clay and silt (Vilas et al. 2005). Elsewhere, particularly in the inner area, fine-grained sediments also persist up to the shoreline. Organic matter content is related to mud distribution, showing higher percentages in the central axis and in the inner and middle ria areas (Diz et al, in press). Elevated values are also found in the southern margin of the inner ría, probably related to the urban wastewater (Vilas et al., 2005).

\section{MATERIALS AND METHODS}

Forty three surface and subsurface sediment samples, taken on a spatial high-resolution basis, were analysed for biogenic opal content. All samples were collected with a box-corer on board the R/V Mytilus (IIM-CSIC) in September 1998 (Fig. 1). Each box core was completely sampled at 1centimetre intervals from the $0-1$ down to $4-5 \mathrm{~cm}$, and also at 2-cm intervals from 5 to $15 \mathrm{~cm}$. Opal determinations were carried out in 43 samples for the uppermost centimetre, 42 samples at the 1-2 and 4-5 cm, 35 samples at the 10-11 cm and in 33 samples at the 14-15 centimetre sediment depth. Additionally, in some stations located in the longitudinal axis, depth-resolution sampling is even every centimetre. 
Sediment samples were stored in plastic bags at $4^{\circ} \mathrm{C}$ until opal analyses were performed in the laboratory. The bulk sediment (approximately $200 \mathrm{mg}$ ) was dried using an oven at a temperature lower than $50^{\circ} \mathrm{C}$, and treated with $5 \mathrm{ml}$ of $\mathrm{HCl}(1 \mathrm{M})$ and $5 \mathrm{ml}$ of $\mathrm{H}_{2} \mathrm{O}_{2}$ (pharmaceutical grade) in order to eliminate carbonate and organic matter. The determination of the amount of opal contained in the bulk sediment was carried out following the wet alkaline leaching procedure devised by Mortlock and Froelich (1989). Biogenic silica was extracted into a $2 \mathrm{M} \mathrm{Na}_{2} \mathrm{CO}_{3}$ solution at $85^{\circ} \mathrm{C}$ for $5 \mathrm{~h}$. Finally, the dissolved silicate concentration present in the extract was measured by means of molybdate blue spectrophotometry using a continuous flow analyser AutoAnalyser Technicon II. Precision of the biogenic silica measurement was evaluated from replicate analyses of selected surface samples from the Ría de Vigo, which have different opal content that cover the entire opal range found in the ría. Standard deviation for 6 to 8 parallel extractions was \pm 0.2 , indicating good reproducibility, though for the opal poor samples (<1.3 wt.\%) relative standard deviation reaches up to $16 \%$ (Bernárdez et al., 2005).

\section{RESULTS AND DISCUSSION}

\subsection{Surface sediment: biogenic silicon fluxes and opal record}

The amount of opal in the surface sediment ranged from almost undetected to a maximum percentage of $3.9 \mathrm{wt.} \%$ with a mean value of $1.70 \mathrm{wt} . \%$ (Fig. 2). Highest concentrations were found in the San Simón Inlet, with values around 3-3.5 wt.\%. In this area, the maximum values (around 3.5 wt.\%) were located in the innermost part (Box 1, Fig. 1), i.e. nearby the Verdugo-Oitabén mouth, and 
the lower ones (3 wt.\%) in the vicinity of the Rande Strait. In the Box 2 (Fig. 1), biogenic silica content decreases to percentages about 2-3 wt.\%, however, higher values were found on the northern shore. Concentrations about 1.5-2 wt.\% were found in Boxes 3 and 4, along its central axis in a lengthwise direction. Lower biogenic silica values were located at the ría mouth channels and persisted up to the shoreline, where the sediments are rich in carbonates and sands. As expected, the amount of opal clearly decreases from the head to the mouth of the ría.

Opal distribution appears well correlated with the sediment structure in the Ría de Vigo. The amount of biogenic silica showed a distribution similar to the muddy fraction and also to low energy processes. Low biogenic silica percentages were found in the entrance channels and the shoreline, where high energy and erosive processes are of remarkable importance and coarser sediment fractions are dominant. That grain size effect in opal distribution has been discussed in Bernárdez et al. (2005) leading to the conclusion that for muddy sediments of the ría the analysis in the finer fraction ( $<63 \mu \mathrm{m}$ fraction) is unnecessary. The percentage of biogenic silica in bulk sediment (without correction of grain size) was chosen to evaluate the biosiliceous production in the water column.

Data about the silicon and carbon fluxes in the Ría de Vigo has been studied in terms of biogeochemical processes and water circulation (Prego, 1993; Prego et al., 1995; Gago et al., 2003), but the benthic-pelagic coupling concerning silicon in the ría has not been developed yet. Further information about this relationship improves our ability to discern seasonal and spatial changes in paleoproductivity from the geological record.

A correlation between the silicon and carbon production rates in the water column and the opal content record in the surface sediment has been found. Elevated silicon and carbon fluxes to the sediment, and thus high primary productivity in the Box 2 matched well with elevated concentrations of biogenic silica in surface sediments. Mean annual value of photosynthesis in the five boxes (Fig. 1, 
Prego, 1993) also shows that highest values are located in the Box 2 and 3 (between Vigo and the Rande Strait, Fig. 1), where high values of opal are recorded in the uppermost oxic layer. Enhanced productivity driving by the upwelling in these boxes was already pointed out (Fraga, 1976). Lower values of primary productivity, found especially in the outer zone, are correlated with a decrease in the amount of opal in the sediment. Thus, as a general view, opal concentrations in the surface sediments are consistent with the spatial changes in productivity along the ría (Bernárdez et al., 2005). Our findings are supported by the amount of organic carbon in the superficial sediment reported by Diz et al. (in press). In the outer area (limit in the station 26, Box 4 and 5, Fig. 1) values are around $2 \%$, whereas in the middle-inner part (Box 3 and 2) organic carbon ranges between $3-$ $4 \%$ being especially high in the innermost stations (Box 1, San Simón Inlet).

We used the dataset reported by Prego et al. (1995) for the calibration of the opal in the sediment as a productivity proxy applying the biogenic silicon deposition in the sediment in each zone of the ría and for different hydrographic and production periods (Table 1). Due to the spatial and temporal heterogeneity of biogenic silicon net deposition data presented in Prego et al. (1995) some calculations were carried out: (i) first, according to the four typical behaviours of the silicon cycle along the year described by Prego et al. (1995) we calculated the biogenic silicon flux to the seabed for both hydrographical situation and boxes; (ii) second, taking into account the mean upwelling index for each month, defining the seasonality in the area, we extrapolated the biogenic silicon flux obtained for each hydrographical situation to the months when these distinctive conditions occur. Thus, values of the biogenic silicon net flux to the sediment $\left(\mathrm{mg} \mathrm{Si} \mathrm{m}^{-2} \mathrm{~d}^{-1}\right)$ for each box were converted to annual values ( $\mathrm{g} \mathrm{Si} \mathrm{m}^{-2}$ year-1), and in addition, we have calculated a mean annual flux deposition of silicon in the five boxes described in Prego et al. (1995). The mean opal content in the first centimetre in each box was estimated with regard to the area covered by each opal isopleths on 
the contour map (Fig. 2). Therefore, we can compare the annual biogenic silicon flux to the seabed (Table 1) with the biogenic silica content in the surface sediment.

Figure 3 shows the linear correlation between the annual biogenic silicon flux and the percentage of opal for each box (excluding Box 1):

$$
\text { Opal }(w t . \%)=0.103 \mathrm{BSiF}+0.414
$$

where $\mathrm{SiF}$ is the biogenic silicon flux to the sediment in $\mathrm{g} \mathrm{Si} \mathrm{m}^{-2}$ year $^{-1}$

The high correlation between both parameters, excluding Box 1, demonstrates the coupling between the benthic (bottom sediment) and the pelagic environment. These quantitative findings are supported by the correlation between the opal record in the surface sediment of the ría and the sink to the bottom of the particles produced by silica-producing organisms. However, since the content of opal is integrated over the full 1 centimetre, this parameter does not reflect short-time temporal variations, being an excellent proxy of long-term spatial and temporal changes in productivity (Rathburn et al., 2001). According to the reported sedimentation rates (Desprat et al. 2003), one centimetre spans approximately five years. The appearance of opal when the silicon deposition flux is zero (see equation 1) is explained by several factors: (i) The seasonal pulses are not sufficient enough to change the background of opal, (ii) Lithogenic silica leaching lead to a slight overestimation of the biogenic silica, because correction for non-biogenic constituents were not applied in the Mortlock and Froelich (1989) technique, (iii) The decrease in the residence time of water when upwelling occurs lead to a transport and export of the biogenic particulate material from the high productivity areas in the inner ría to the outer zone. This lateral transport of biogenic silica due to positive residual circulation might increase the opal percentage in the sediment. However, slow transport currents (Souto et al., 2003) and the low water column depth allow the sedimentation of most of the biosiliceous compounds in the production area. 
Data of the biogenic silicon fluxes and the opal content in the Box 1 need special attention. Contrary to what may be expected, the highest values of biogenic silica recorded in the Box 1 (San Simón Inlet) are not related to an enhanced net primary production. Biogenic silica percentage in the first centimetre in the San Simón Inlet is considerably higher than predicted by the linear correlation. Therefore, at least, a second source of biogenic silica to the bottom sediment must be invoked. The most reliable explanation is the presence of a important contribution of opal due to the siliceous benthic production. Scanning electron microscope (SEM) images of the most common benthic diatom groups and species (Cocconeis, Diploneis, Psammodyction, Achnanthes, Amphora and Paralia sulcata) were obtained (Fig. 4). These groups and species have a high abundance in the San Simón Inlet surface sediment samples, instead of planktonic forms such as Chaetoceros resting spores, Thalassionema nitzschioides or Thalassiosira, commonly found commonly found in the sediments of the medium and outer ría (Bao et al. 1989).

The contribution of the benthic siliceous production was calculated using the equation (1). The opal content expected in the Box 1 concerning only the input of pelagic biosiliceous flux (13.53 g Si $\mathrm{m}^{-2}$ year-1, Fig. 3) is $1.80 \mathrm{wt} . \%$, according to the equation (1). The difference between the opal percentage found (3.16 wt.\%, Fig. 3) and expected (1.80 wt.\%) is the contribution owing to the benthic diatoms. Around $43 \%$ of the biogenic silica found in the surface sediments of the San Simón Inlet is due to the benthic biosiliceous production:

$$
\% \text { BenthicOpal }=(1.36 \% / 3.16 \%) \times 100=43 \%
$$

The high opal content due to microbenthic production is related to an increase of the intertidal environments, the resistance of the benthic diatoms to dissolution (Varela and Penas, 1985), the nutrient inputs (Gago et al., 2005), and the shallower depths. However, the contribution of the benthic 
biosiliceous organisms may be overestimated due to the biogenic silica supply from other sources, e.g. freshwater diatoms. The abundance of the freshwater group is low in comparison with the benthic assemblage as detected by means of scanning electron microscopy. Low sediment suspended loads in the Verdugo-Oitabén river were found (Pérez-Arlucea et al., 2005), and the river-borne suspended matter entering the Inlet is dominated by clay minerals, quartz and feldspar; organic matter consists mainly of Fe-rich algae and occasional diatoms (Pazos et al. 2000). However, several freshwater species were identified by Bao et al. (1989), even in the medium ría.

There are also a large number of mussel rafts in the outer part of the Inlet. These rafts contain strings of mussels (Mytilus galloprovincialis), that concentrate fine-grained sediment to produce faecal mud, which is ultimately deposited in the adjacent ría floor. San Simón Inlet acts a sediment trap to muddy sediments (Nombela et al., 1995). Thus, high concentrations of the diatoms frustules in the faecal pellets raise the opal content in the Inlet.

\subsection{Subsurface sediment: postdepositional processes}

Linkages between biological, hydrological and sedimentological processes in the recent sedimentary record are important to understand the limitations and usefulness of the opal productivity

proxy in the geological record. A detailed study of the biogenic silica content in the subsurface sediment was carried out for understanding post-depositional processes that could have an effect on the opal record.

Results of opal concentration at different sediment depths are shown in Figure 2. Contour plot of opal at $1-2 \mathrm{~cm}$ depth showed the same distribution and analogous values as compared to the pattern found in the surface sediments. However, in the Box 2 (Fig. 1), a distinctive trend was found, 
characterised by higher opal percentages close to the northern shoreline (ca. 2.8 wt.\%). This pattern was also identified in the surface sediments.

Several differences were found at $4-5 \mathrm{~cm}$ depth with regard to previous results. First, the mean opal content $(1.9 \mathrm{wt} . \%)$ is higher than in surface sediments. The decrease in the percentage of opal from the Verdugo-Oitabén mouth to the Rande Strait area, as recorded in the upper centimetres, is blurred. Second, the higher percentages of biogenic silica detected for the previous centimetres in the Box 2, close to the northern shore, was not identified at this sediment depth. The amount of biogenic silica in the central axis of the ría becomes higher, reaching values up to $2 \mathrm{wt} . \%$.

Biogenic silica distribution showed a distinguished pattern at 10-11 cm depth, characterised by elevated values in the vicinity of Rande Strait and in the outermost area of the San Simón Inlet, ranging from 3 to $5 \mathrm{wt} . \%$. Moreover, higher biogenic silica percentages were found in the longitudinal axis, up to $2.5 \mathrm{wt} . \%$.

The contour map at $14-15 \mathrm{~cm}$ depth closely resembles the one found for the previous depths studied. The highest percentages of opal were found in the vicinity of Rande Strait. However, opal content in this area was slightly lower than the at $10-11 \mathrm{~cm}$ depth (with values around $4.2 \mathrm{wt} . \%$ ). In the longitudinal axis in Box 4 (Fig. 1), biogenic silica percentage ranged between 2-2.4 wt.\%.

According to the amount of opal, and as observed in the longitudinal axis section, two areas can be clearly distinguished (Fig. 5). The limit is located between the stations 36 and 41 and represents the high-low productivity boundary. In the outer area (Box 4 and 5), opal values are lower, especially in the two upper centimetres (Fig. 2). Generally speaking, opal profiles show lower values in the first or even the second centimetre. Due to the lack of data about benthic silicon dissolution rates along the profiles in the Ría de Vigo, this fact could be interpreted as a fast remineralization of 
the "fresh" biosiliceous material at the oxic sediment-water interface. The presence of the fluffy layer and the associated lower sediment density can also play a role in this trend.

In the Box 2, opal concentrations in the subsurface sediments are high, especially in the station 45. The high concentration of opal registered at $10-11 \mathrm{~cm}$ depth in the vicinity of Rande Strait can be explained by one or the combination of several factors: 1) A rise in the primary productivity at the period of burial 2) A decrease in the input of lithogenic particles, and 3) An enhanced preservation efficiency of the opal due to the establishment of suboxic-anoxic conditions during burial. The latter is particularly important in areas of an elevated high primary production, and it is linked to oxygen consumption because of the remineralization of organic matter during burial. Although areas of highest opal concentration seem to be coupled with the biosiliceous pelagic productivity, the hindered diagenetic processes and oxic-anoxic conditions in the sediments controls the opal accumulation in the sediment. Dissolved oxygen values near the seabed in the Ría de Vigo shows that the sedimentwater interface is oxic (Doval et al., 1998), but in muddy sediments without bioturbation, as in these stations, oxic-anoxic limit is very close to the surface sediment Abella et al (1998). Recent studies in the Ría de Arousa indicated strongly reducing environments in these type of sediments, with mean Eh values that ranging between $-120 \pm 20$ and $-252 \pm 60 \mathrm{mV}$ and $\mathrm{pH}$ values varying from 8 to 8.7 (Otero et al., in press). Diz et al. (in press) also shows that in the most inner settings of the Ría de Vigo degradation processes of organic carbon could cause low oxygen and/or reducing conditions in the sediment affecting negatively the benthic foraminifera populations. Lack of burrowing and a reduced ventilation of the sediment also increase the opal preservation efficiency. Thus, preservation of the opal in this area is strongly influenced by the arrival of large amounts of organic matter and the establishment of reducing conditions during burial. 
As explained previously, the most common opal-depth profile is characterized by a decrease in the amount of opal in the upper centimetres, but other trends can be found locally. Some stations in the northern shore in the Box 2 showed a higher amount of opal in the two upper centimetres (Stations 38 and 34, Fig. 5). The anti-clockwise circulation in this area, cross to the ría axis (Montero et al. 1999) seems to explain the more intense deposition of fine particles, as diatom frustules, in the northern shoreline and the reduction of the sedimentation of the biosiliceous compounds in the southern margin. The high input of faecal pellets with elevated concentrations of diatom frustules derived from the nearby mussel rafts could also increase the amount of opal in the sediments in this zone due to the high number of these structures in the area.

In the cross-section of the outer area lower opal concentrations were found, even in the subsuperficial sediment (Fig. 5). This pattern is linked to the coarser sediment structure at the margins as well as higher bottom currents (Diz et al., 2004). Values around 2.2-2.4 wt.\% at the station 26 between $5-11 \mathrm{~cm}$ sediment depth are associated to the establishment of a lower energy environment (Souto et al., 2003) and the deposition of muddy sediments in the central axis of the ría.

\section{CONCLUSIONS}

The benthic-pelagic equation (1) presents an evaluation of the linking between biosiliceous production and the record in the sediments. The biogenic silicon flux to the seabed follows the same trend as the opal content in the surface sediments, confirming the usefulness of opal as a proxy of paleoproductivity in ría environments, as well as estuarine, coastal and shelf areas with high primary productivity. Elevated values of opal found in the San Simón Inlet are mainly due to the growth of 
benthic diatoms. The input of freshwater diatoms from the Verdugo-Oitabén River and the concentration of diatom frustules in faecal pellets also increases slightly the biogenic silica content in that area. The anti-clockwise circulation in the inner areas could enhance the deposition of biosiliceous particles in the northern margin. In the outer area, lower values of opal are related to a decrease in the primary productivity and the coarser sediment structure.

Different patterns of opal accumulation were recognized in the subsurface sediment, responding to changes in the opal accumulation, postdepositional processes or to the input of diatom frustules in the faecal pellets derived from the mussel rafts. Typical opal-depth profiles, particularly those of stations located in the longitudinal mud patch, are characterized by a slight decrease in the amount of opal in the upper centimetres. High values of biogenic silica in the inner area (Box 2) in the subsuperficial sediment $(11-15 \mathrm{~cm})$ are related to the development of a reducing environment that enhances the opal preservation due to the oxidation of organic matter in this high productivity area.

\section{Acknowledgements}

The authors would like to express their gratitude to Roberto Bao, Antonio Cobelo-García and Carlos Souto for the valuable comments on the manuscript and for helping improve and correcting the English. We are also indebted to M. A. Barcena and O. E. Romero for their help with diatom identification. Marta Elena González and Daniel Caride are sincerely acknowledged for their technical assistance in laboratory processing. This work was supported for the METRIA REN2003-04106-C03, REN2003-09394, EVK2-CT-2000-00060, PGIDT04PXIC31204PN and PGIDT00MAR30103PR projects. P.B. would like to thank the Xunta de Galicia (Secretaría Xeral de Investigación e Desenvolvemento) and Ministerio de Educación, Cultura y Deporte (Secretaría de Estado de Educación y Universidades) for financial support. 


\section{References}

Abella, E., Parada, J.M., Mora, J., 1998. Perfiles de óxido-reducción de los sedimentos infralitorales de dos Rías Baixas. In: Servicio de Publicacións da Universidade de Vigo (ed.) XIII congreso bienal de la Real Sociedad Española de Historia Natural, Libro de Resúmenes, pp. 134.

Álvarez-Salgado, X.A., Rosón, G., Pérez, F.F, Pazos, Y., 1993. Hydrographic variability off the Rías Baixas (NW Spain) during the upwelling season. Journal of Geophysical Research 98(C8), 14447-14455.

Bao, R., Rey, J., Varela, M., 1989. Las diatomeas como indicadores paleoecológicos en las costas de Galicia (NW de España): Diatomeas de sedimentos superficiales de la Ría de Vigo. Cadernos do Laboratorio Xeolóxico de Laxe 14, 133-158.

Bao, R., Varela, M., Prego, R., 1997. Mesoscale distribution patterns of diatoms in surface sediments as tracers of coastal upwelling of the Galician shelf (NW Iberian Peninsula). Marine Geology $144,117-130$.

Barciela, M.C., Bao, R., Prego, R., Herbello, P., 2000. El ópalo en el sedimento superficial de la Ría de Pontevedra: distribución y comparación con las rías (Arosa y Vigo) y plataforma adyacentes. In: Duarte, A., Vale, C., Prego, R. (Eds.), Estudos de Biogeoquímica na Zona Costeira lbérica. Universidade de Aveiro, Aveiro, Portugal, pp. 153-158.

Bernárdez, P., Prego, R., Francés, G., González-Álvarez, R., 2005. Opal content in the Ría de Vigo and Galician continental shelf: biogenic silica in the muddy fraction as an accurated paleoproductivity proxy. Continental Shelf Research 25, 1249-1264.

Cobelo-García, A., Prego, R., 2004. Influence of point sources on trace metal contamination and distribtion in a semi-enclosed industrial embayment: the Ferrol Ria (NW Spain). Estuarine, Coastal and Shelf Science, 60, 695-703. doi:10.1016/j.ecss.2004.03.008

Dale, A.W., Prego, R., 2002. Physico-biogeochemical controls on benthic-pelagic coupling of nutrient fluxes and recycling in a coastal upwelling system. Marine Ecology Progress Series $235,15-28$.

DeMaster, D.J., 1981. The supply and accumulation of silica in the marine environment. Geochimica et Cosmochimica Acta 45, 1715-1732.

Desprat, S., Sánchez-Goñi, M.F., Loutre, M.F., 2003. Revealing climatic variability of the last three millennia in northwestern Iberia using pollen influx data. Earth and Planetary Science Letters 213, 63-78. doi:10.1016/S0012-821X(03)00292-9

Diz, P., Frances, G., Costas, S., Souto, C. and Alejo, I., 2004. Distribution of benthic foraminifera in coarse sediments, Ría de Vigo, NW Iberian margin. Journal of Foraminiferal Research 34, $258-275$. 
Diz, P., Francés, G., Rosón , G., in press. Effects of contrasting upwelling-downwelling on benthic foraminiferal distribution in the Ría de Vigo (NW Spain). Journal of Marine Systems. doi:10.1016/j.jmarsys.2005.11.001

Doval, M.D., Nogueira, E., Pérez, F.F., 1998. Spatio-temporal variability of the thermohaline and biogeochemical properties and dissolved organic carbon in a coastal embayment affected by upwelling: the Ría de Vigo (NW Spain). Journal of Marine Systems 14, 135-150.

Evans, G., Prego, R., 2003. Rias, estuaries and incised valleys: is a ria an estuary? Marine Geology 196, 171-175. doi:10.1016/S0025-3227(03)00048-3

Fraga, F., 1976. Fotosíntesis en la ría de Vigo. Investigación Pesquera 40, 151-167.

Fraga, F., 1981. Upwelling off the Galician coast, northwest of Spain. In: Richards, F. (Ed.), Coastal Upwelling. American Geophysical Union, Washington, pp. 176-182.

Gago, J, Álvarez-Salgado, X.A., Gilcoto, M, Pérez, F.F., 2003. Assessing the contrasting fate of dissolved and suspended organic carbon in a coastal upwelling system ("Ría de Vigo", NW Iberian Peninsula). Estuarine, Coastal and Shelf Science 56, 271-279. doi:10.1016/S02727714(02)00186-5

Gago, J., Álvarez-Salgado, X.A., Nieto-Cid, M., Brea, S. Piedracoba, S., 2005. Continental inputs of C, N, P and Si species to the Ría de Vigo (NW Spain). Estuarine, Coastal and Shelf Science 65, 74-82. doi:10.1016/j.ecss.2005.05.008

Moncoiffé G., Álvarez-Salgado X.A., Figueiras F., Savidge G., 2000. Seasonal and short-time-scales dynamics of microplankton community production and respiration in an inshore upwelling system. Marine Ecology Progress Series 196, 111-126.

Montero, P., Gómez-Gesteira, M., Taboada, J.J., Ruiz-Villarreal, M., Santos, A.P., Neves, R.R., Prego, R., Pérez-Villar, V., 1999. On residual circulation of the Ria of Vigo, using a 3-D baroclinical model. Boletin del Instituto Español de Oceanografía 15, 31-38.

Mortlock, R.A., Froelich, P., 1989. A simple method for the rapid determination of biogenic opal in pelagic marine sediments. Deep-Sea Research 36, 1415-1426.

Nelson, D.M., Tréguer, P., Brzezinski, M.A., Leynaert, A., Quéquiner, B., 1995. Production and dissolution of biogenic silica in the ocean: revised global estimates, comparison with regional data and relationship to biogenic sedimentation. Global Biogeochemical Cycles 9, 359-372.

Nombela, M.A., Vilas, F., Evans, G., 1995. Sedimentation in the mesotidal Rías Bajas of Galicia (north-western Spain): Ensenada de San Simón, Inner Ría de Vigo. Special Publications International Association of Sedimentologist, 24: 133-149.

Otero, X.L.,. Calvo de Anta, R.M, Macías, F., in press. Sulphur partitioning in sediments and biodeposits below mussel rafts in the Ría de Arousa (Galicia, NW Spain). Marine Environmental Research.

Pasow, U., Engel, A., Ploug, H., 2003. The role of aggregation for the dissolution of diatom frustules. FEMS Microbiology Ecology 46, 247-255. doi:10.1016/S0168-6496(03)00199-5

Pazos O, Nombela M.A, Vilas F., 2000. Continental contribution of suspended sediment to an estuary: Ría de Vigo. Scientia Marina64, 295-302. 
Pérez-Arlucea, M., Filgueira, M., Freijido, M., Méndez, G., 2000. Parámetros morfométricos e hidrológicos de las cuencas de drenaje y ríos tributarios a la ría de Vigo. Estimación de las variaciones anuales en las cargas en suspensión y en disolución. Cuadernos de Geología Ibérica 26: 171-187.

Perez-Arlucea, M., Mendez, G., Clemente, F., Nombela, M., Rubio, B., Filgueira, M., 2005. Hydrology, sediment yield, erosion and sedimentation rates in the estuarine environment of the Ria de Vigo, Galicia, Spain. Journal of Marine Systems 54, 209-226. doi: 10.1016/j.jmarsys.2004.07.013

Pokras, E.M., 1986. Preservation of fossil diatoms in Atlantic sediment cores: control by supply rate. Deep-Sea Research 33, 893-902.

Prego, R. 1993. General aspects of carbon biogeochemistry in the ría of Vigo, northwestern Spain. Geochimica et Cosmochimica Acta 57, 2041-2052.

Prego, R., Bao, R., 1997. Upwelling influence on the Galician coast: silicate in shelf water and underlying surface sediments. Continental Shelf Research 17, 307-318.

Prego, R., Bao, R., Howland, R., 1995. The biogeochemical cycling of dissolved silicate in a Galician Ría. Ophelia 42, 301-318.

Prego, R., Fraga, F., 1992. A simple model to calculate the residual flows in a spanish ría. Hydrographic consequences in the ría of Vigo. Estuarine, Coastal and Shelf Science 34, 603615.

Ragueneau, O., Tréguer, P., Leynaert, A., Anderson, R.F., Brzezinski, M.A., DeMaster, D.J., Dugdale, R.C., Dymond, J., Fischer, G., François, R., Heinze, C., Maier-Reimer, E., MartinJézéquel, V., Nelson, D.M., Quéquiner, B., 2000. A review of the Si cycle in the modern ocean: Recent progress and missing gaps in the application of biogenic opal as a paleoproductivity proxy. Global and Planetary Change 26, 317-365.

Ragueneau, O., Gallinari, M., Corrin, L., Grandel, S., Hall, P., Hauvespre, A., Lampitt, R.S., Rickert, D., Stahl, H., Tengberg, A., Witbaard, R., 2001. The benthic silica cycle in the Northeast Atlantic: annual mass balance, seasonality and importance of non-steady-state processes for the early diagenesis of biogenic opal in deep-sea sediments. Progress in Oceanography 50, 171-200.

Rathburn, A.E., Perez, M.E., Lange, C.B., 2001. Benthic-pelagic coupling in the Southern California Bight: Relationships between sinking organic material, diatoms, benthic foraminifera. Marine Micropaleontology 43, 261-271.

Souto, C., Gilcoto, M., Fariña-Busto, L., Pérez, F.F., 2003. Modeling the residual circulation of a coastal embayment affected by wind-driven upwelling: Circulation of the Ría de Vigo (NW Spain). Journal of Geophysical Research 108 (C11), 3340. doi: 10.1029/2002JC001512

Tilstone, G.H., Figueiras, F.G:, Fermín, E.G., Arbones, B., 1999. Significance of nanophytoplankton photosyntesis and primary production in a coastal upwelling system (Ría de Vigo, NW Spain). Marine Ecology Progress Series 183, 13-27. 
van Bennekom, A.J., Buma, A.G.J., Nolting, R.F., 1991. Dissolved aluminium in the Weddell-Scotia confluence and effect of Al on the dissolution kinetics of biogenic silica. Marine Chemistry 35, 423-434.

Varela, M., Penas, E., 1985. Primary production of benthic microalgae in an intertidal sand flat of the Ría de Arosa, NW Spain. Marine Ecology Progress Series 25, 111-119.

Van Cappellen, P., Qiu, L., 1997. Biogenic silica dissolution in sediments of the Southern Ocean: I. Solubility. Deep-Sea Research 44, 1109-1128.

Vilas, F., Bernabeu, A., M., Mendez, G., 2005. Sediment distribution pattern in the Rias Baixas (NW Spain): main facies and hydrodynamic dependence. Journal of Marine Systems 54, 261-276. doi:10.1016/j.jmarsys.2004.07.016 
Figure 1. Map of the Ría de Vigo showing the sampling stations. Bathymetric lines every $10 \mathrm{~m}$ depth.

Figure 2. Contour plots of the distribution of opal percentage in the Ría de Vigo at different sediment depths. Contour lines every $0.2 \mathrm{wt} . \%$ opal. Colour scale from light to dark grey indicates the increase in the opal percentage.

Figure 3. Plot showing the linear correlation between the mean annual silicon flux to the seabed and the mean opal content in the first centimetre of the sediment in each box considered in Prego et al. (1995). Box 1, located in the San Simón Inlet, was not included in the regression. Equation of the linear regression also shown (BSiF represents the biogenic silicon flux).

Figure 4. SEM images of some benthic diatom species found in the San Simón Inlet (surface sediment samples $49,50,51,52,53,54)$. a) b) c) d) e) f) Cocconeis spp. g) h) i) Diploneis spp. j) k) Psammodyction spp. I) Paralia sulcata m) n) Achnanthes spp. o) Amphora sp.

Figure 5. Plot of the percentage of opal from the top down to $15 \mathrm{~cm}$ in the longitudinal and crosssection of the Ría de Vigo. Stations used for the longitudinal and cross-section is indicated in the map. Sample number at the top of every contour plot.

Table 1. Biogenic silicon flux data (annual mean) for both boxes and different hydrographical situations (winter, spring, summer with upwelling and summer without upwelling). Original data from Prego et al (1995) is also presented in brackets ( $\left.\mathrm{mg} \mathrm{Si} \mathrm{m}^{-2} \mathrm{~d}^{-1}\right)$ and represents the biogenic silicon flux to the sediment for each hydrographical condition. 
Click here to download Manuscript: Tables.doc

\begin{tabular}{ccccccc}
\hline Period & $\begin{array}{c}\text { Time spans } \\
\text { (months) }\end{array}$ & Box 1 & Box 2 & Box 3 & Box 4 & Box 5 \\
\hline Winter & 4 & $(13) 1560$ & $\left(-605^{*}\right) 0$ & $(0) 0$ & $(-4)-480$ & $(6) 720$ \\
Spring & 3 & $(19) 1710$ & $(49) 4410$ & $(17) 1530$ & $(11) 990$ & $(14) 1260$ \\
Summer with upwelling & 2 & $(159) 9540$ & $(82) 4920$ & $(172) 10320$ & $(46) 2760$ & ND \\
Summer without upwelling & 3 & $(8) 720$ & $(124) 11160$ & $(5) 450$ & $(14) 1260$ & ND \\
\hline Total BSi flux (g Si m mear $^{-1}$ ) & & 13.53 & 20.49 & 12.3 & 4.53 & 1.98 \\
\hline
\end{tabular}

${ }^{*}$ Not considered in the calculations. Net biogenic silicon flux to the seabed in winter in Box 2 is considered zero.

ND: No Data 


\section{Figure1}

Click here to download high resolution image

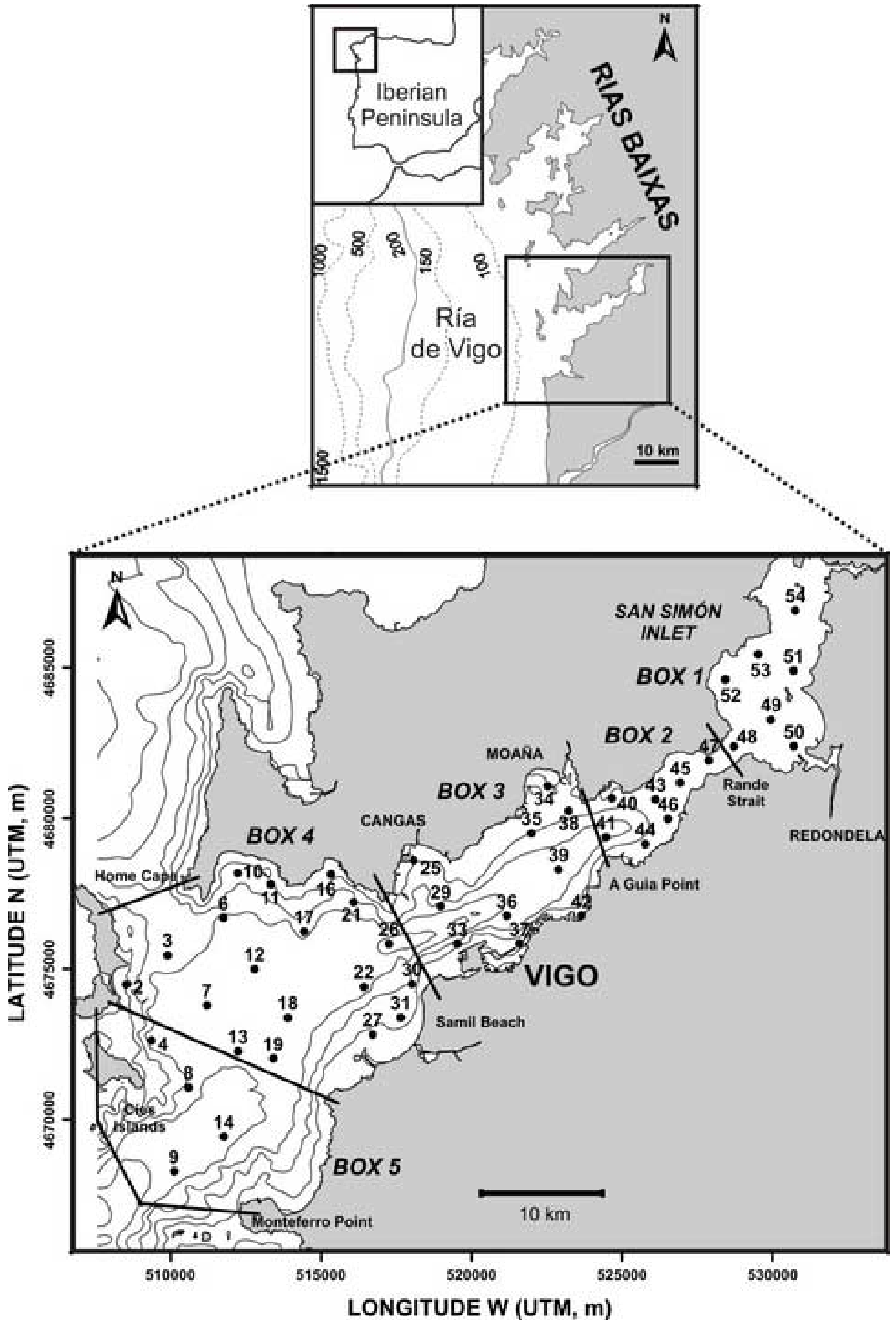



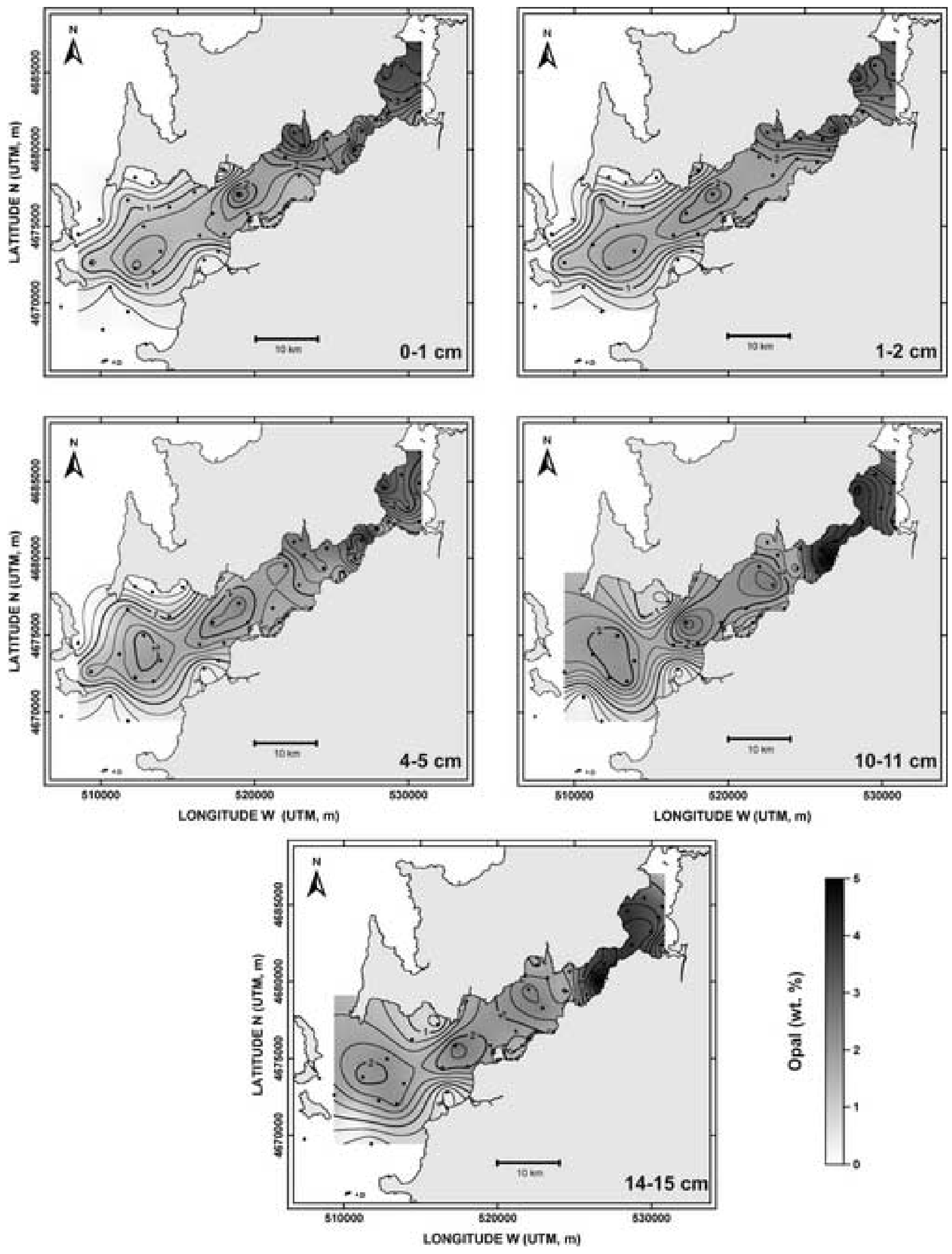
Click here to download high resolution image

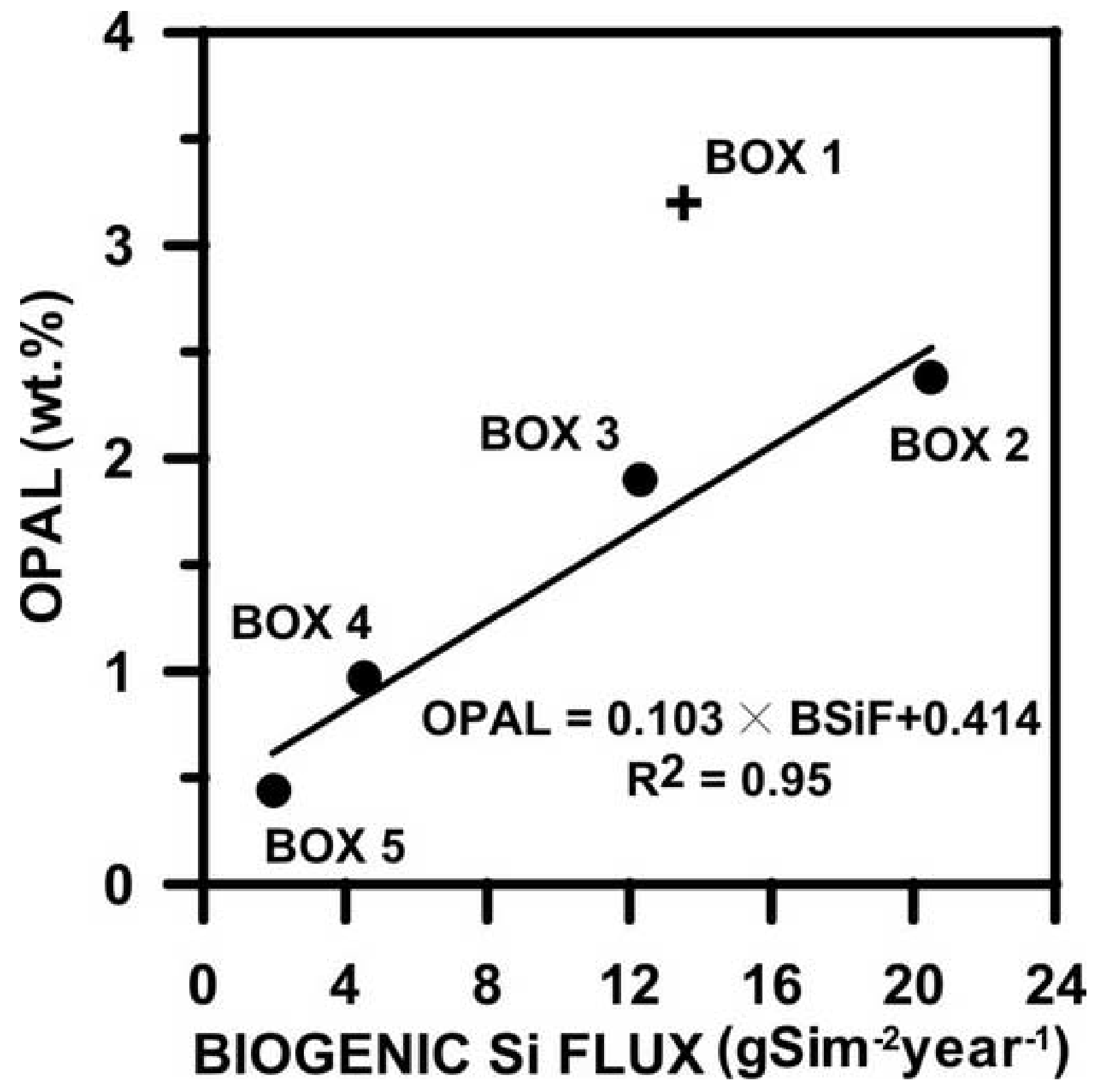




\section{Click here to download high resolution image}
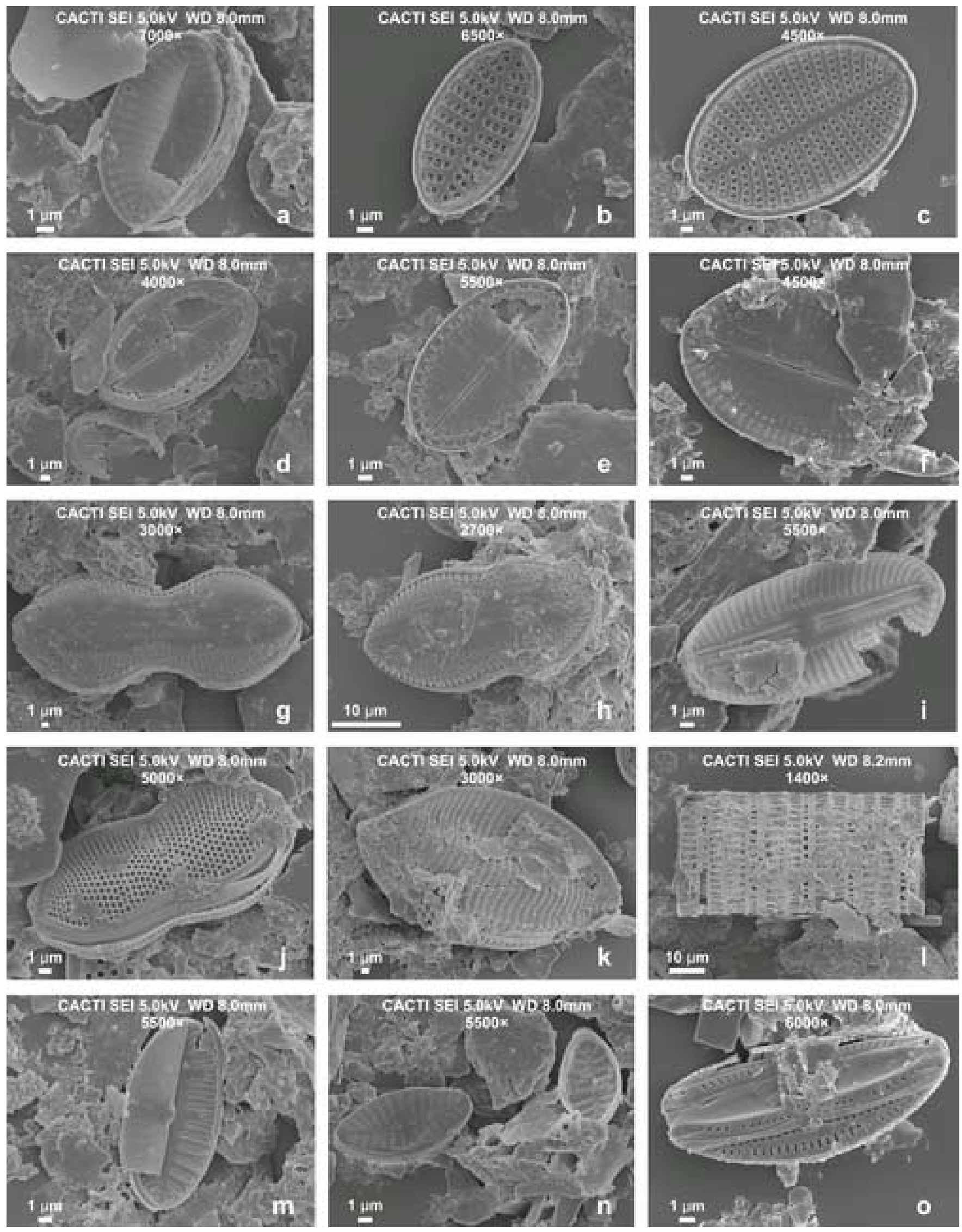


\section{Click here to download high resolution image}
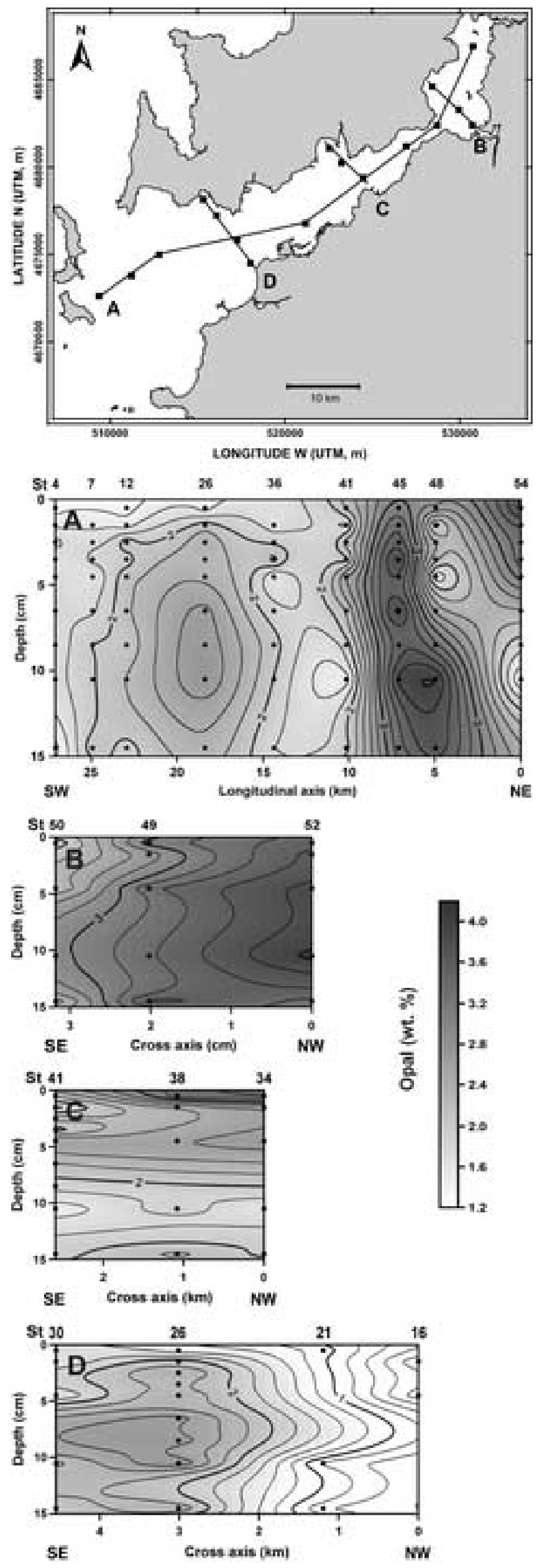


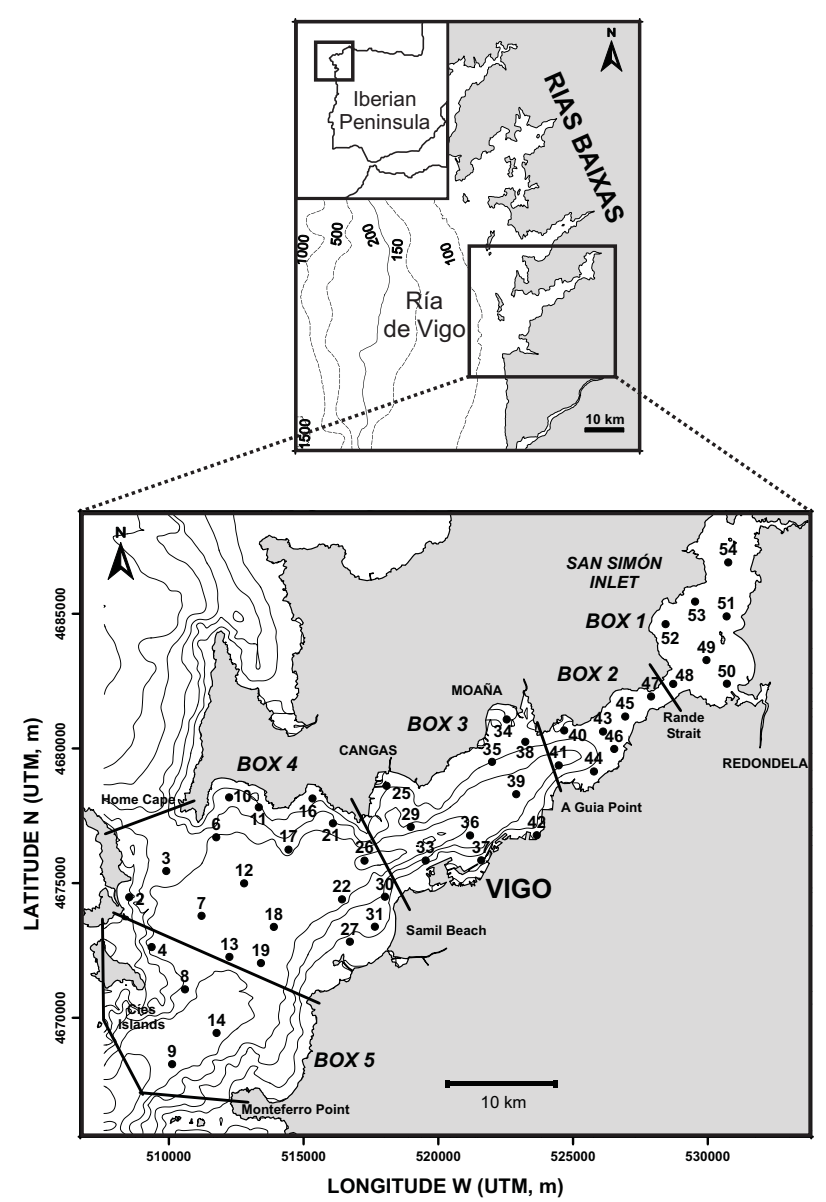

Figure 1 

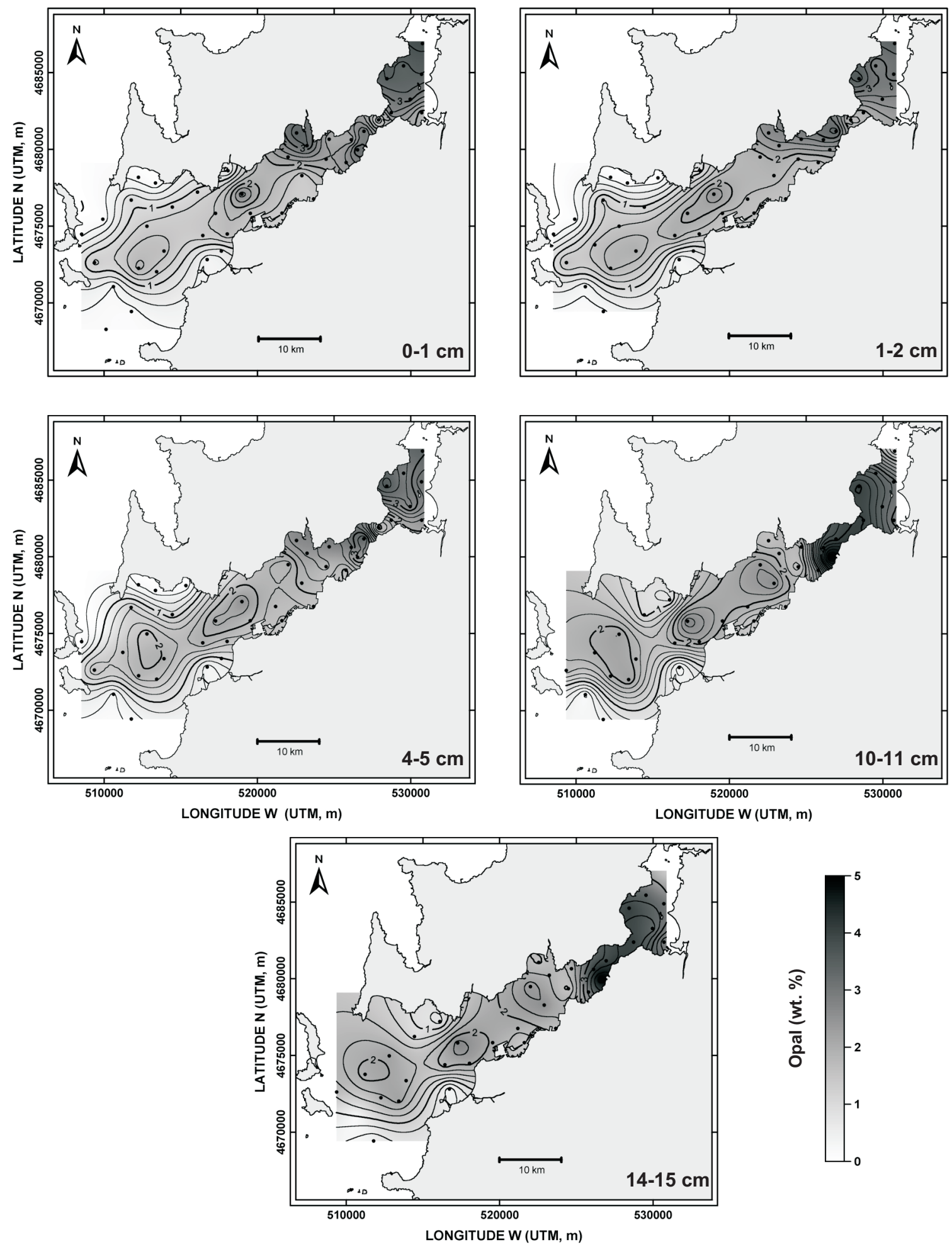


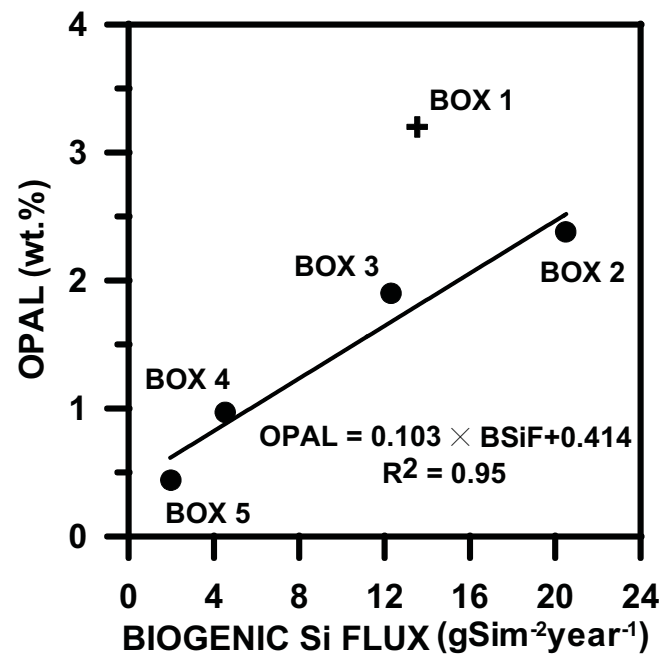

Figure 3 

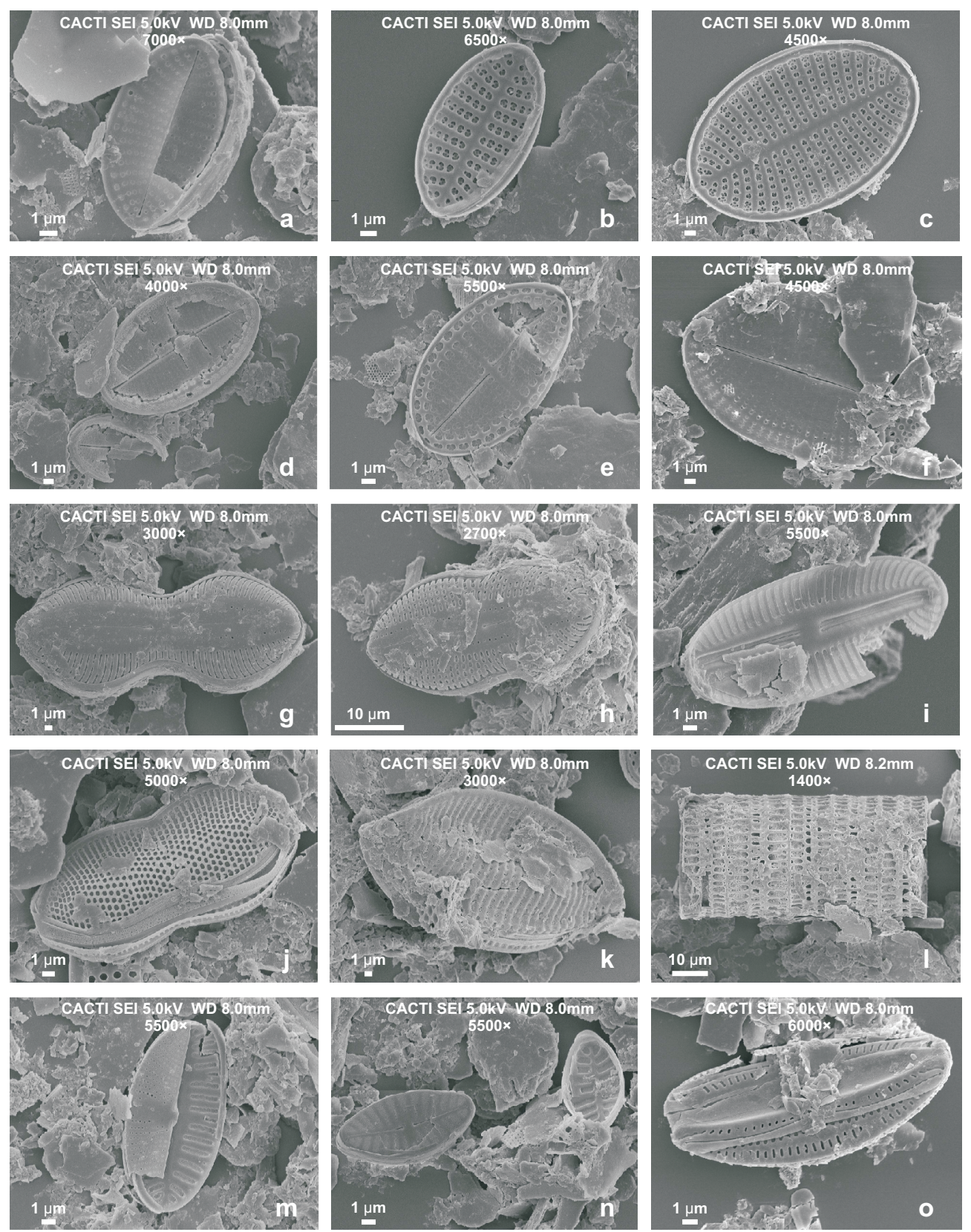

Figure 4 

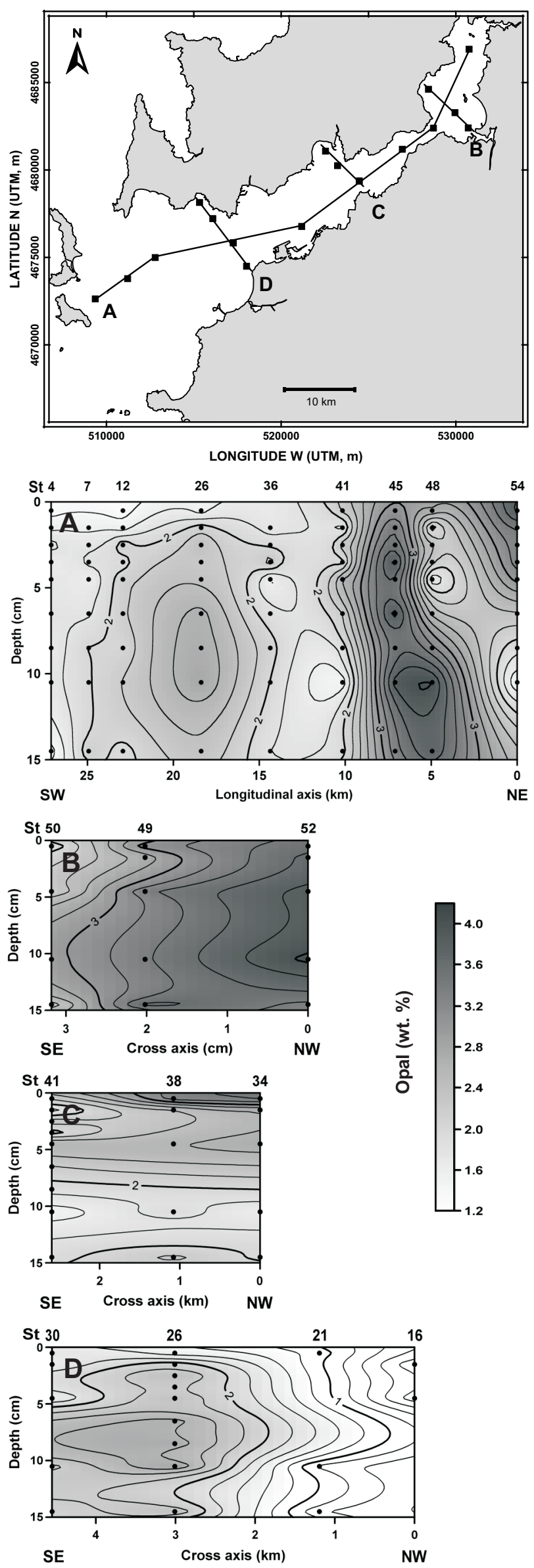

Figure 5 